\title{
Wpływ wapnowania i dodatku materiałów organicznych na zawartość niklu w kupkówce pospolitej oraz we frakcjach w glebie zanieczyszczonej tym pierwiastkiem
}

\begin{abstract}
Streszczenie: Badano wpływ zanieczyszczenia gleby niklem $\left(0,75,150\right.$ i $225 \mathrm{mg} \mathrm{Ni} \mathrm{kg}{ }^{-1}$ gleby) na tle zróżnicowanego wapnowania ( $0 \mathrm{Ca}$ i Ca w g $1 \mathrm{Hh}$ ) i materiałów organicznych (bez stosowania materiałów organicznych, słoma żytnia i węgiel brunatny z Kopalni Węgla Brunatnego Turów) na zawartość niklu w kupkówce pospolitej i frakcje tego metalu w glebie. Analizowano cztery pokosy kupkówki pospolitej zebrane w trzecim roku doświadczenia wazonowego oraz oznaczono frakcje niklu w glebie pobranej po ostatnim pokosie rośliny testowej. Zawartość niklu w roślinie oraz ogólną zawartość tego pierwiastka w glebie oznaczono metodą ICP-AES po wcześniejszej mineralizacji. Frakcje niklu w glebie oznaczono metodą frakcjonowania sekwencyjnego - BCR. Wprowadzenie do gleby niklu, niezależnie od ilości, spowodowało istotne zwiększenie jego zawartości w biomasie kupkówki pospolitej oraz w glebie we wszystkich frakcjach, przede wszystkim we frakcji wymiennej $\left(\mathrm{F}_{1}\right)$. Wapnowanie gleby oraz aplikacja materiałów organicznych zmniejszyły zawartość niklu w biomasie kupkówki pospolitej oraz w glebie we frakcji wymiennej, bezpośrednio przyswajalnej przez rośliny, powodując jednocześnie zwiększenie jego udziału we frakcji rezydualnej (wapnowanie) oraz redukowalnej i utlenialnej (aplikacja materiałów organicznych).
\end{abstract}

Stowa kluczowe: kupkówka pospolita, nikiel, gleba, metoda BCR

\section{WSTĘP}

Rozwój przemysłu, postępująca urbanizacja, zwiększenie produkcji nawozów i środków ochrony roślin przyczyniają się do zanieczyszczenia kolejnych elementów środowiska naturalnego człowieka: gleby, wód powierzchniowych i gruntowych oraz roślin (Węglarczyk 2001, Kuziemska i Kalembasa 2013). Główne zanieczyszczenia stanowią związki ropopochodne, WWA oraz metale ciężkie (Wowkonowicz i in. 2001). Szczególnie niebezpieczne są metale ciężkie, ponieważ jako pierwiastki nie ulegają biodegradacji i przez wiele lat moga zalegać w ekosystemach (Gorlach i Gambuś 2000). W przypadku metali ciężkich ważna jest nie tylko ich całkowita zawartość w próbkach środowiskowych, ale przede wszystkim formy (frakcje) w jakich występują (Campel i Nikel 2006, Jaremko i Kalembasa 2011). Ich rozmieszczenie w poszczególnych frakcjach świadczy o potencjalnej biodostępności (Rauret i in. 1999, Jeske i Gworek 2011, Świetlik i Trojanowska 2009, Jaremko i Kalembasa 2011, Jakubus 2012).

Jednym z metali ciężkich, którego ilość w środowisku systematycznie się zwiększa, jest nikiel. Z powodu swej toksyczności i wysokiego współczynnika bioakumulacji znalazł się w II Wykazie Komisji Europejskiej (Dyrektywa o substancjach toksycznych) (Eisler 2000, Nakonieczny 2007).

Celem przeprowadzonego eksperymentu było zbadanie wpływu wapnowania i zróżnicowanego nawożenia organicznego na rozmieszczenie niklu we frakcjach oznaczonych według procedury BCR w glebie, a także określenie ich wpływu na zawartość $\mathrm{Ni} \mathrm{w}$ kupkówce pospolitej uprawianej na glebie zanieczyszczonej tym metalem.

\section{MATERIAŁY I METODYKA BADAŃ}

W badaniach przeprowadzono analizę biomasy czterech pokosów kupkówki pospolitej, zebranej w trzecim roku doświadczenia wazonowego oraz gleby pobranej po ostatnim pokosie rośliny testowej. Doświadczenie przeprowadzono na terenie stacji doświadczalnej Uniwersytetu Przyrodniczo-Humanistycznego w Siedlcach, w latach 2009-2011, w czterech powtórzeniach. Uwzględniono w nim następujące czynniki:

1) zanieczyszczenie gleb niklem: 0 (bez stosowania niklu), 75, 150 i $225 \mathrm{mg} \mathrm{Ni} \mathrm{kg}^{-1}$ gleby;

2) wapnowanie: $0 \mathrm{Ca}$ (bez wapnowania) i $\mathrm{Ca} \mathrm{wg}$ 
$1 \mathrm{Hh}$ (wapnowanie w dawce wyliczonej według 1 kwasowości hydrolitycznej gleby);

3) materiały organiczne: bez stosowania materiałów organicznych (0); słoma żytnia w dawce $1,33 \mathrm{~g} \mathrm{~kg}^{-1}$ gleby; węgiel brunatny (pochodzący z Kopalni Węgla Turów) w dawce 13,3 $\mathrm{g} \mathrm{kg}^{-1}$ gleby. Skład chemiczny obu stosowanych materiałów organicznych podano w tabeli 1.

TABELA 1. Skład chemiczny materiałów organicznych (słomy żytniej i węgla brunatnego) zastosowanych w doświadczeniu wazonowym

TABLE 1. Chemical composition of organic materials (rye straw and brown coal) used in pot experiment

\begin{tabular}{llll}
\hline $\begin{array}{l}\text { Składnik } \\
\text { Component }\end{array}$ & $\begin{array}{l}\text { Jednostka } \\
\text { Unit }\end{array}$ & $\begin{array}{l}\text { Słoma żytnia } \\
\text { Rye straw }\end{array}$ & $\begin{array}{l}\text { Wegiel brunatny } \\
\text { Brown coal }\end{array}$ \\
\hline $\begin{array}{l}\text { Sucha masa } \\
\text { Dry matter }\end{array}$ & $\mathrm{g} \cdot \mathrm{kg}^{-1}$ & 850 & 850 \\
\hline Corg & $\mathrm{g} \mathrm{kg}^{-1} \mathrm{~s} . \mathrm{m}$. & 432 & 541 \\
$\mathrm{~N}$ & & 4,22 & 4,00 \\
$\mathrm{P}$ & & 0,64 & 0,11 \\
$\mathrm{~K}$ & & 2,00 & 0,84 \\
\hline $\mathrm{Ni}$ & $\mathrm{mg} \mathrm{kg}{ }^{-1}$ s.m. & 3,84 & 5,10 \\
\hline
\end{tabular}

Glebę o składzie granulometrycznym piasku gliniastego lekkiego pobrano z poziomu próchnicznego $(0-20 \mathrm{~cm})$ gleby płowej spiaszczonej (Albic Luvisol). W materiale glebowym przed założeniem doświadczenia oznaczono: $\mathrm{pH}$ w roztworze $\mathrm{KCl}$ o stężeniu $1 \mathrm{~mol} \mathrm{dm}^{-3}$ metodą potencjometryczną wg PN-ISO-10390; zawartość azotu ogólnego metoda analizy elementarnej na autoanalizatorze CHN z detektorem przewodności cieplnej (ICD), serie II 2400 firmy Perkin-Elmer; zawartość fosforu i potasu przyswajalnego metodą Egnera-Riehma wg PN-R-040022; zawartość węgla organicznego metodą oksydacyjnomiareczkową wg PN-ISO-14235 oraz zawartość form ogólnych niklu metodą atomowej spektrometrii emisyjnej z plazmą indukcyjnie wzbudzoną (ICP-AES), aparatem firmy Perkin-Elmer Optima 3200 RL, po wcześniejszej mineralizacji $\mathrm{w}$ mieszaninie kwasów nadchlorowego i azotowego w stosunku 1:2. W stosowanych w doświadczeniu materiałach organicznych zawartość węgla oznaczono metodą oksydacyjnomiareczkową, azotu metodą analizy elementarnej, fosforu, potasu i niklu metodą ICP-AES. Zawartość suchej masy oznaczono metodą suszarkowo-wagową wg PN-75/C/041616.01. Gleba użyta do doświadczenia wazonowego miała następujące właściwości: $\mathrm{pH}$ w zawiesinie materiału glebowego i $\mathrm{KCl}$ o stężeniu $1 \mathrm{~mol} \mathrm{dm}^{-3}$ - 5,5; zawartość azotu ogólnego $0,98 \mathrm{~g} \mathrm{~kg}^{-1}$; węgla w związkach organicznych $7,9 \mathrm{~g} \mathrm{~kg}^{-1}$; fosforu przyswajalnego $69 \mathrm{mg} \mathrm{kg}^{-1}$ gleby, potasu przyswajalnego $75 \mathrm{mg} \mathrm{kg}^{-1}$ gleby, niklu ogólnego $5,67 \mathrm{mg}$ $\mathrm{Ni} \mathrm{kg}{ }^{-1}$ gleby.

Wapnowanie (w formie $\mathrm{CaCO}_{3}$ ), dodatek materiału organicznego (węgiel brunatny i słomę żytnią pociętą na sieczkę) oraz nikiel (w formie wodnego roztworu $\mathrm{NiSO}_{4} 7 \mathrm{H}_{2} \mathrm{O}$ ) wprowadzono do gleby jednorazowo w listopadzie 2008 roku. W tak przygotowanym materiale glebowym umieszczonym w wazonach o pojemności $15 \mathrm{dm}^{3}$, zawierających $10 \mathrm{~kg}$ gleby, wiosną 2009 roku wysiano roślinę testową kupkówkę pospolitą (Dactylis glomerata L.), której każdego roku badań zbierano po cztery odrosty (pokosy) co $30 \mathrm{dni}$. W okresie wegetacyjnym w wazonach utrzymywano wilgotność gleby na poziomie $60 \%$ PPW. W glebie pobranej po zbiorze ostatniego pokosu (trzeci rok badań) oznaczono: ogólną zawartość Ni ICP-AES, po wcześniejszej mineralizacji w mieszaninie kwasów nadchlorowego i azotowego (stosunek 1:2) oraz $\mathrm{pH}$ w roztworze $\mathrm{KCl}$ o stężeniu $1 \mathrm{~mol} \mathrm{dm}{ }^{3}$ metodą potencjometryczną. Frakcje niklu oznaczono metodą frakcjonowania sekwencyjnego, zaproponowana przez Community Bureau of Reference (BCR) (Rauret $i$ in. 1999), której schemat przedstawiono w tabeli 2. Zawartość niklu w biomasie kup-

TABELA 2. Schemat metody frakcjonowania sekwencyjnego zaproponowanej przez Community Bureau of Reference (BCR) (Rauret $i$ in. 1999)

TABLE 2. A diagram of the BCR sequential extraction method according to Rauret et al. (1999)

\begin{tabular}{llll}
\hline $\begin{array}{l}\mathrm{Nr} \\
\mathrm{No} .\end{array}$ & $\begin{array}{l}\text { Nazwa frakcji } \\
\text { Name of fractions }\end{array}$ & $\begin{array}{l}\text { Odczynniki ekstrakcyjne } \\
\text { Extraction reagents }\end{array}$ & $\mathrm{pH}$ \\
\hline $\mathrm{F}_{1}$ & $\begin{array}{l}\text { Wymienna, łatwo rozpuszczalna } \\
\text { W środowisku kwaś nym } \\
\text { Exchangeable and acid solube }\end{array}$ & $0,1 \mathrm{M} \mathrm{CH}_{3} \mathrm{COOH}$ & 3,0 \\
\hline $\mathrm{F}_{2}$ & $\begin{array}{l}\text { Redukowalna } \\
\text { Reducible }\end{array}$ & $0,5 \mathrm{M} \mathrm{NH} \mathrm{OH}_{2} \cdot \mathrm{HCl}$ & 1,5 \\
\hline $\mathrm{F}_{3}$ & $\begin{array}{l}\text { Utlenialna } \\
\text { Oxidisable }\end{array}$ & $8,8 \mathrm{M} \mathrm{H}_{2} \mathrm{O}_{2}+1 \mathrm{M} \mathrm{CH}_{3} \mathrm{COONH}_{4}$ & 2,0 \\
\hline $\mathrm{F}_{4}$ & $\begin{array}{l}\text { Rezydualna } \\
\text { (poekstrakcyjna pozostałość }) \\
\text { Residual }\end{array}$ & $\begin{array}{l}\text { Obliczone z różnicy pomiędzy zawartoś cią całkowita } \\
\text { a sumą trzech wcześniej wydzielonych frakcji } \\
\text { Calculated as difference between total conten } \\
\text { and sum three previously separated fractions }\end{array}$ & - \\
\hline
\end{tabular}


kówki pospolitej oznaczono metodą ICP-AES, po wcześniejszej mineralizacji materiałów w piecu muflowym w temperaturze $450^{\circ} \mathrm{C}$ przez 8 godzin i rozpuszczeniu popiołu w $10 \%$ roztworze $\mathrm{HCl}$.

Wyniki badań opracowano statystycznie, poddając je analizie wariancji z wykorzystaniem rozkładu F-Fishera-Snedecora, z użyciem programu Statistica 10 PL (Statsoft, Tulsa, USA), a wartość $\mathrm{NIR}_{(0,05)}$ wyliczono wg testu Tukey'a.

\section{WYNIKI BADAŃ I DYSKUSJA}

Kabata-Pendias i Pendias (1999) podaja, że zawartość niklu w trawach mieści się $\mathrm{w}$ przedziale od 0,01 do $19 \mathrm{mg} \mathrm{kg}^{-1}$, średnio $0,84 \mathrm{mg} \mathrm{kg}^{-1}$ s.m. Zawartość niklu w biomasie badanej kupkówki pospolitej wynosiła od 9,06 $\mathrm{mg} \mathrm{kg}^{-1}$ s.m. (rośliny uprawiane na obiektach kontrolnych) do $358,6 \mathrm{mg} \mathrm{kg}^{-1}$ s.m. (rośliny uprawiane na obiektach, gdzie zastosowano $225 \mathrm{mg} \mathrm{Ni} \mathrm{kg}{ }^{-1}$ gleby) (tab. 3).

TABELA 3. Zawartość niklu ( $\mathrm{mg} \mathrm{kg}^{-1}$ s.m.) w biomasie kupkówki pospolitej TABLE 3. The content ( $\left.\mathrm{mg} \mathrm{kg}^{-1} \mathrm{DM}\right)$ of nickel in the biomass of cocksfoot

\begin{tabular}{|c|c|c|c|c|c|c|c|}
\hline \multirow[t]{2}{*}{$\begin{array}{l}\text { Wapnowanie } \\
\text { Liming }\end{array}$} & \multirow[t]{2}{*}{$\begin{array}{l}\text { Materiały organiczne } \\
\text { Organic materials }\end{array}$} & \multirow{2}{*}{$\begin{array}{l}\text { Nikiel } \\
\text { (mg kg-1 gleby) } \\
\text { Nickel } \\
\left(\mathrm{mg} \mathrm{kg}^{-1} \text { of soil) }\right.\end{array}$} & \multicolumn{4}{|l|}{$\begin{array}{l}\text { Pokos } \\
\text { Cut }\end{array}$} & \multirow[t]{2}{*}{$\begin{array}{l}\text { Ś rednia } \\
\text { Mean }\end{array}$} \\
\hline & & & I & II & III & IV & \\
\hline \multirow[t]{3}{*}{$\begin{array}{l}\text { Bez Ca } \\
\text { Without liming }\end{array}$} & $\begin{array}{l}\text { Bez mat. organicznego } \\
\text { Without organic } \\
\text { materials }\end{array}$ & $\begin{array}{r}0 \\
75 \\
150 \\
225 \\
\end{array}$ & $\begin{array}{r}11,36 \\
108,60 \\
221,00 \\
358,60 \\
\end{array}$ & $\begin{array}{r}18,14 \\
109,40 \\
214,80 \\
342,10 \\
\end{array}$ & $\begin{array}{r}21,06 \\
92,10 \\
206,60 \\
284,10 \\
\end{array}$ & $\begin{array}{r}30,08 \\
84,12 \\
218,40 \\
308,10\end{array}$ & $\begin{array}{r}20,16 \\
98,56 \\
215,20 \\
323,20 \\
\end{array}$ \\
\hline & $\begin{array}{l}\text { Słoma żytnia } \\
\text { Rye straw }\end{array}$ & $\begin{array}{c}0 \\
75 \\
150 \\
225\end{array}$ & $\begin{array}{r}12,18 \\
100,40 \\
200,40 \\
300,40 \\
\end{array}$ & $\begin{array}{r}17,46 \\
84,16 \\
192,40 \\
264,50\end{array}$ & $\begin{array}{r}22,08 \\
82,12 \\
168,60 \\
282,10\end{array}$ & $\begin{array}{r}29,18 \\
64,04 \\
172,10 \\
243,00\end{array}$ & $\begin{array}{r}20,23 \\
82,68 \\
183,40 \\
272,50 \\
\end{array}$ \\
\hline & $\begin{array}{l}\text { Wegiel brunatny } \\
\text { Brown coal }\end{array}$ & $\begin{array}{r}0 \\
75 \\
150 \\
225 \\
\end{array}$ & $\begin{array}{r}10,80 \\
100,00 \\
197,40 \\
306,40 \\
\end{array}$ & $\begin{array}{r}16,22 \\
74,12 \\
188,00 \\
302,80 \\
\end{array}$ & $\begin{array}{r}19,84 \\
65,04 \\
154,20 \\
290,40 \\
\end{array}$ & $\begin{array}{r}27,14 \\
68,00 \\
163,50 \\
284,60 \\
\end{array}$ & $\begin{array}{r}18,50 \\
76,79 \\
175,80 \\
296,10 \\
\end{array}$ \\
\hline \multirow[t]{3}{*}{$\begin{array}{l}\mathrm{Ca} \\
\text { Liming }\end{array}$} & $\begin{array}{l}\text { Bez mat. organicznego } \\
\text { Without organic } \\
\text { materials }\end{array}$ & $\begin{array}{c}0 \\
75 \\
150 \\
225 \\
\end{array}$ & $\begin{array}{r}10,03 \\
76,40 \\
148,00 \\
208,60 \\
\end{array}$ & $\begin{array}{r}15,42 \\
74,12 \\
142,10 \\
192,40\end{array}$ & $\begin{array}{r}18,18 \\
72,00 \\
124,40 \\
192,00\end{array}$ & $\begin{array}{r}24,16 \\
60,00 \\
146,20 \\
158,40 \\
\end{array}$ & $\begin{array}{r}16,95 \\
70,63 \\
140,20 \\
187,90 \\
\end{array}$ \\
\hline & $\begin{array}{l}\text { Słoma żytnia } \\
\text { Rye straw }\end{array}$ & $\begin{array}{c}0 \\
75 \\
150 \\
225 \\
\end{array}$ & $\begin{array}{r}10,43 \\
69,40 \\
128,00 \\
200,10 \\
\end{array}$ & $\begin{array}{r}15,00 \\
50,22 \\
126,40 \\
180,20\end{array}$ & $\begin{array}{r}20,03 \\
52,14 \\
108,60 \\
172,40\end{array}$ & $\begin{array}{r}21,18 \\
50,04 \\
112,00 \\
146,20\end{array}$ & $\begin{array}{r}16,66 \\
55,45 \\
118,80 \\
174,70 \\
\end{array}$ \\
\hline & $\begin{array}{l}\text { Wegiel brunatny } \\
\text { Brown coal }\end{array}$ & $\begin{array}{r}0 \\
75 \\
150 \\
225 \\
\end{array}$ & $\begin{array}{r}9,06 \\
70,04 \\
129,30 \\
194,60 \\
\end{array}$ & $\begin{array}{r}11,24 \\
60,02 \\
143,80 \\
180,20 \\
\end{array}$ & $\begin{array}{r}12,48 \\
54,16 \\
132,20 \\
160,40 \\
\end{array}$ & $\begin{array}{r}15,23 \\
52,10 \\
120,00 \\
158,40 \\
\end{array}$ & $\begin{array}{r}12,00 \\
59,06 \\
131,30 \\
173,40 \\
\end{array}$ \\
\hline \multicolumn{2}{|c|}{$\begin{array}{l}\text { Ś rednie dla wapnowania } \\
\text { Mean for liming }\end{array}$} & $\begin{array}{l}\text { Bez Ca } \\
\text { Without liming } \\
\text { Ca Liming }\end{array}$ & $\begin{array}{l}160,60 \\
104,50\end{array}$ & $\begin{array}{r}152,00 \\
99,26\end{array}$ & $\begin{array}{l}140,70 \\
93,25\end{array}$ & $\begin{array}{r}141,00 \\
88,70\end{array}$ & $\begin{array}{r}148,60 \\
96,42\end{array}$ \\
\hline \multicolumn{2}{|c|}{$\begin{array}{l}\text { Ś rednie dla materiałów organicznych } \\
\text { Mean for organic materials }\end{array}$} & $\begin{array}{l}\text { Bez mat. org. } \\
\text { Without organic } \\
\text { materials } \\
\text { Słoma żytnia } \\
\text { Rye straw } \\
\text { Węgiel brunatny } \\
\text { Brown coal }\end{array}$ & $\begin{array}{l}127,70 \\
127,20\end{array}$ & $\begin{array}{l}116,30 \\
122,10\end{array}$ & $\begin{array}{l}113,50 \\
111,10\end{array}$ & $\begin{array}{l}104,70 \\
111,10\end{array}$ & $\begin{array}{l}115,60 \\
117,90\end{array}$ \\
\hline \multicolumn{2}{|c|}{$\begin{array}{l}\text { Ś rednie dla dawek niklu } \\
\text { Mean for nickel doses }\end{array}$} & $\begin{array}{c}0 \\
75 \\
150 \\
225 \\
\end{array}$ & $\begin{array}{r}10,64 \\
87,47 \\
170,70 \\
261,50\end{array}$ & $\begin{array}{r}15,58 \\
75,34 \\
167,90 \\
243,70 \\
\end{array}$ & $\begin{array}{r}18,95 \\
69,59 \\
149,10 \\
230,20\end{array}$ & $\begin{array}{r}24,50 \\
63,04 \\
155,40 \\
216,50 \\
\end{array}$ & $\begin{array}{r}17,42 \\
73,86 \\
160,80 \\
238,00 \\
\end{array}$ \\
\hline \multicolumn{2}{|c|}{$\begin{array}{l}\mathrm{NIR}_{0,05} \text { dla: } \\
\mathrm{LSD}_{0.05} \text { for: } \\
\text { - dawek niklu, doses for nickel } \\
\text { - wapnowania, liming } \\
\text { - materiałów organicznych, organic materials }\end{array}$} & $\begin{array}{l}\text { I pokos } \\
\text { Cut } \\
65,29 \\
\text { n.i. } \\
\text { n.i. }\end{array}$ & $\begin{array}{l}\text { II pokos } \\
\text { Cut } \\
35,45 \\
18,76 \\
\text { n.i. }\end{array}$ & $\begin{array}{l}\text { III pokos } \\
\text { Cut } \\
26,06 \\
14,06 \\
\text { n.i. }\end{array}$ & $\begin{array}{l}\text { IV pokos } \\
\text { Cut } \\
29,13 \\
15,41 \\
\text { n.i. }\end{array}$ & & \\
\hline
\end{tabular}

n.i. nie istotne, not significant 
TABELA 4. Wartość pH gleby w roztworze $\mathrm{KCl}$ o stężeniu $1 \mathrm{~mol} \mathrm{dm}^{-1}$

TABLE 4. The $\mathrm{pH}$ of soil in $1 \mathrm{~mol} \mathrm{dm}^{-1} \mathrm{KCl}$ solution

\begin{tabular}{|c|c|c|c|c|c|c|c|c|}
\hline \multirow[t]{3}{*}{$\begin{array}{l}\text { Obiekty } \\
\text { Objects }\end{array}$} & \multicolumn{4}{|c|}{$\mathrm{Bez} \mathrm{Ca}$} & \multicolumn{4}{|c|}{$\begin{array}{l}\text { Ca wg } 1 \text { Hh gleby } \\
\text { Ca acc. to } 1 \text { hydrolytic acidity }\end{array}$} \\
\hline & \multicolumn{8}{|c|}{$\begin{array}{l}\text { Nikiel (mg kg-1 }{ }^{-1} \text { leby) } \\
\text { Nickel (mg kg-1 of soil) }\end{array}$} \\
\hline & $\overline{0}$ & 75 & 150 & 225 & 0 & 75 & 150 & 225 \\
\hline $\begin{array}{l}\text { Bez mat. organicznych } \\
\text { Without organic materials }\end{array}$ & 5,36 & 5,29 & 5,26 & 5,30 & 6,38 & 6,36 & 6,40 & 6,38 \\
\hline $\begin{array}{l}\text { Słoma żytnia } \\
\text { Rye straw }\end{array}$ & 5,16 & 5,14 & 5,20 & 5,16 & 6,25 & 6,22 & 6,20 & 6,30 \\
\hline $\begin{array}{l}\text { Węgiel brunatny } \\
\text { Brown coal }\end{array}$ & 5,76 & 5,72 & 5,70 & 5,68 & 6,46 & 6,50 & 6,54 & 6,52 \\
\hline
\end{tabular}

$\mathrm{NIR}_{0,05}$ dla:

$\mathrm{LSD}_{0.05}$ for:

- dawek niklu, doses of nickel n.i.

- wapnowania, liming 0,040

- materiałów organicznych, organic materials 0,062

W roślinach zebranych z obiektów, w których zanieczyszczono glebę niklem, niezależnie od pokosu i bez względu na ilość Ni wprowadzoną do gleby, stwierdzono zwiększenie jego zawartości powyżej wartości uznanych przez Kabatę-Pendias i Pendiasa (1999) za naturalna, czyli $19 \mathrm{mg} \mathrm{kg}^{-1}$. Zawartość niklu w biomasie rośliny testowej zwiększyła się nie tyle ze względu na zwiększenie całkowitej zawartości Ni w glebie, ile przede wszystkim ze względu na zwiększenie udziału Ni we frakcji wymiennej (tab. 5 i 6). Zastosowane wapnowanie spowodowało istotne zmniejszenie zawartości niklu w roślinach zebranych w pokosach II-IV, natomiast w pokosie I stwierdzono tendencję do obniżenia zawartości niklu w roślinach uprawianych na glebie wapnowanej, co jest zgodne z wynikami otrzymanymi przez Domańską (2009) oraz wcześniejszymi wynikami uzyskanymi przez Kuziemską (2009). W przeprowadzonych badaniach nie wykazano istotnego wpływu zastosowanych materiałów organicznych (słomy żytniej i węgla brunatnego) na zawartość niklu w biomasie kupkówki pospolitej. Niemniej rośliny wszystkich pokosów zebranych z obiektów, na których zastosowano te materiały, charakteryzowały się mniejszą zawartością niklu niż biomasa roślin zebranych z obiektów kontrolnych. W przypadku słomy żytniej średnio o $13,8 \%$, w przypadku węgla brunatnego średnio o $12,2 \%$. Wpływ różnych materiałów organicznych na zmniejszenie bioprzyswajalności niklu i innych metali stwierdzili w swoich badaniach Gibczyńska i Stankowski (2011) oraz Molas (2010).

Jednym z czynników, które mają znaczący wpływ na mobilność niklu w glebie, jest wartość pH (Jaworska $\mathrm{i}$ in. 2013). W tabeli 4 podano wartości $\mathrm{pH}$ analizowanej gleby po zakończeniu doświadczenia, ozna- czone w roztworze $\mathrm{KCl}$ o stężeniu $1 \mathrm{~mol} \mathrm{dm}^{-3}$, które mieściły się $\mathrm{w}$ przedziale od 5,14 do 6,54 . W badaniach nie wykazano istotnego wpływu zróżnicowanej zawartości niklu w glebie na wartość pH. Głównym elementem różnicującym wartość $\mathrm{pH}$ gleby było wapnowanie. Pomimo że od zastosowania $\mathrm{CaCO}_{3}$ minęły trzy lata, wykazano jego istotny wpływ na wzrost wartości $\mathrm{pH}$ gleby. $\mathrm{W}$ doświadczeniu stwierdzono również wpływ na wartość $\mathrm{pH}$ gleby zastosowanych materiałów organicznych (słomy żytniej i węgla brunatnego). Niezależnie od wapnowania, na obiektach, na których zastosowano słomę żytnią, stwierdzono niższe wartości $\mathrm{pH}$ gleby, natomiast na obiektach, na których zastosowano węgiel brunatny wyższe, w porównaniu $\mathrm{z}$ wartościami $\mathrm{pH}$ gleby uzyskanymi $\mathrm{z}$ obiektów, na których materiałów organicznych nie zastosowano (tab. 4).

Zawartość niklu w badanych frakcjach wydzielonych według procedury BCR oraz ich procentowy udział w zawartości ogólnej w analizowanej glebie przedstawiono w tabelach 5 i 6 . Największą zawartość Ni stwierdzono w glebie, do której wprowadzono go w dawce $225 \mathrm{mg} \mathrm{kg}^{-1}$ gleby, a najmniejszą w glebie z obiektów kontrolnych, gdzie jego zawartość była naturalna. Na ogół na obiektach, na których zastosowano nikiel, największą jego zawartość wydzielono we frakcji wymiennej $\left(\mathrm{F}_{1}\right)$. Po trzech latach badań udział niklu w tej frakcji na obiektach zanieczyszczonych sięgał nawet $64 \%$ zawartości całkowitej tego pierwiastka w glebie. Zastosowane wapnowanie spowodowało zmniejszenie udziału $\mathrm{Ni}$ we frakcji wymiennej $\left(\mathrm{F}_{1}\right)$, redukowalnej $\left(\mathrm{F}_{2}\right)$ i utlenialnej $\left(\mathrm{F}_{3}\right)$ oraz zwiększenie jego udziału we frakcji rezydualnej $\left(\mathrm{F}_{4}\right)$, co świadczy o jego unieruchomieniu $\mathrm{i}$ jest zbieżne $\mathrm{z}$ rezultatami uzyskanymi przez Badorę (2002), która wykazała zmniejszenie mobilności niklu i innych metali na skutek zwiększenia wartości pH gleby. Zastosowane materiały organiczne spowodowały zmniejszenie udziału badanego pierwiastka we frakcji wymiennej $\left(\mathrm{F}_{1}\right)$ oraz rezydualnej $\left(\mathrm{F}_{4}\right)$, a także zwiększe- 
TABELA 5. Zawartość niklu ( $\mathrm{mg} \mathrm{kg}^{-1}$ gleby) w analizowanej glebie we frakcjach oznaczonych według procedury BCR TABLE 5. The content ( $\mathrm{mg} \mathrm{kg}^{-1}$ of soil) of nickel in fractions determined by the BCR method in the analysed soil

\begin{tabular}{|c|c|c|c|c|c|c|c|}
\hline \multirow[t]{2}{*}{$\begin{array}{l}\text { Wapnowanie } \\
\text { Liming }\end{array}$} & \multirow[t]{2}{*}{$\begin{array}{l}\text { Materiały organiczne } \\
\text { Organic materials }\end{array}$} & \multirow{2}{*}{$\begin{array}{l}\text { Nikiel } \\
\text { (mg kg-1 gleby) } \\
\text { Nickel } \\
\left(\mathrm{mg} \mathrm{kg}^{-1} \text { of soil) }\right.\end{array}$} & \multicolumn{4}{|l|}{$\begin{array}{l}\text { Frakcje } \\
\text { Fraction }\end{array}$} & \multirow[t]{2}{*}{$\begin{array}{l}\text { Suma } \\
\text { Sum }\end{array}$} \\
\hline & & & $\mathrm{F}_{1}$ & $\mathrm{~F}_{2}$ & $\mathrm{~F}_{3}$ & $\mathrm{~F}_{4}$ & \\
\hline \multirow{12}{*}{$\begin{array}{l}\text { Bez Ca } \\
\text { Without liming }\end{array}$} & Bez mat. org. & 0 & 0,38 & 0,62 & 1,08 & 3,20 & 5,28 \\
\hline & Without organic & 75 & 50,01 & 9,26 & 5,82 & 13,01 & 78,10 \\
\hline & materials & 150 & 78,12 & 14,20 & 11,84 & 44,04 & 148,20 \\
\hline & & 225 & 120,20 & 26,12 & 21,08 & 60,20 & 227,60 \\
\hline & Słoma żytnia & 0 & 0,32 & 0,68 & 2,46 & 2,10 & 5,56 \\
\hline & Rye straw & 75 & 32,00 & 11,20 & 28,05 & 8,75 & 80,00 \\
\hline & & 150 & 61,80 & 20,06 & 43,12 & 29,14 & 154,12 \\
\hline & & 225 & 108,60 & 31,12 & 61,56 & 26,97 & 228,30 \\
\hline & Węgiel brunatny & 0 & 0,36 & 0,70 & 2,38 & 2,18 & 5,62 \\
\hline & Brown coal & 75 & 30,20 & 11,85 & 29,98 & 7,17 & 79,20 \\
\hline & & 150 & 53,90 & 18,48 & 39,16 & 42,74 & 154,30 \\
\hline & & 225 & 95,78 & 25,10 & 49,16 & 58,41 & 228,50 \\
\hline \multirow{12}{*}{$\begin{array}{l}\text { Ca } \\
\text { Liming }\end{array}$} & Bez mat. org. & 0 & 0,32 & 0,52 & 1,19 & 3,28 & 5,31 \\
\hline & Without organic & 75 & 32,14 & 6,24 & 7,28 & 33,34 & 79,00 \\
\hline & materials & 150 & 54,22 & 12,80 & 14,36 & 67,22 & 148,60 \\
\hline & & 225 & 100,64 & 21,04 & 19,16 & 77,76 & 218,60 \\
\hline & Słoma żytnia & 0 & 0,30 & 0,52 & 1,90 & 2,88 & 5,60 \\
\hline & Rye straw & 75 & 28,05 & 8,46 & 26,12 & 17,42 & 80,05 \\
\hline & & 150 & 49,18 & 15,90 & 38,40 & 50,76 & 154,20 \\
\hline & & 225 & 97,15 & 25,08 & 40,04 & 66,51 & 228,80 \\
\hline & Węgiel brunatny & 0 & 0,30 & 0,49 & 1,42 & 3,47 & 5,68 \\
\hline & Brown coal & 75 & 29,15 & 8,46 & 21,06 & 20,59 & 79,26 \\
\hline & & 150 & 50,04 & 16,54 & 32,12 & 55,71 & 154,40 \\
\hline & & 225 & 85,16 & 20,83 & 39,19 & 83,84 & 229,00 \\
\hline Ś rednie dla wa & wania & $\mathrm{Bez} \mathrm{Ca}$ & 52,64 & 14,12 & 24,64 & 24,83 & 115,70 \\
\hline Mean for liming & & Without liming & & & & & \\
\hline & & Ca Liming & 43,89 & 11,41 & 20,19 & 40,23 & 116,50 \\
\hline Ś rednie dla ma & łów organicznych & Bez mat. org. & 54,50 & 11,35 & 10,23 & 37,76 & 113,80 \\
\hline Mean for organ & naterials & $\begin{array}{l}\text { Without organic } \\
\text { materials }\end{array}$ & & & & & \\
\hline & & $\begin{array}{l}\text { Słoma żytnia } \\
\text { Rye straw }\end{array}$ & 47,18 & 14,13 & 30,21 & 25,57 & 117,10 \\
\hline & & $\begin{array}{l}\text { Węgiel brunatny } \\
\text { Brown coal }\end{array}$ & 43,11 & 12,81 & 26,81 & 34,26 & 117,00 \\
\hline Ś rednie dla da & niklu & 0 & 0,33 & 0,59 & 1,74 & 2,85 & 5,51 \\
\hline Mean for liming & & 75 & 33,59 & 9,25 & 19,72 & 16.71 & 79,27 \\
\hline & & 150 & 57,88 & 16,33 & 29,83 & 48,27 & 152,30 \\
\hline & & 225 & 101,26 & 24,88 & 38,37 & 62,28 & 226,80 \\
\hline $\begin{array}{l}\mathrm{NIR}_{0,05} \text { dla: } \\
\mathrm{LSD}_{0.05} \text { for: }\end{array}$ & & $\mathrm{F}_{2}$ & $\mathrm{~F}_{3}$ & $\mathrm{~F}_{4}$ & $\begin{array}{l}\text { Suma } \\
\text { sum }\end{array}$ & & \\
\hline - dawek niklu, $\mathrm{d}$ & for nickel & 1,95 & 0,94 & 5,61 & 16,23 & & \\
\hline - wapnowania, li & & 1,18 & 2,30 & 2,80 & n.i. & & \\
\hline - materiałów org & znych, organic materials & 0,64 & 0,64 & 0,94 & n.i. & & \\
\hline
\end{tabular}

nie udziału we frakcji redukowalnej $\left(\mathrm{F}_{2}\right)$ i utlenialnej $\left(\mathrm{F}_{3}\right)$ (tab. 5 i 6 ). Ograniczenie mobilności niklu polega prawdopodobnie na włączeniu go w struktury związków organicznych występujących w glebie. Molas (2010) podaje, że w fazie stałej gleby nikiel jest kompleksowany przede wszystkim przez wchodzące w jej skład substancje humusowe. Jednocześnie metal ten może również koordynować z zawartymi w roztworze glebowym niskocząsteczkowymi związkami organicznymi, takimi jak: amidy, aminy, aminokwasy, węglowodany (głównie mono- i disacharydy), alifatyczne i aromatyczne kwasy hydroksylowe, kwasy fulwowe i huminowe (Molas 2010). Związki te mogą powstawać z mineralizacji substancji organicznej zawartej we wprowadzonych do gleby materiałach organicznych - słomie żytniej i węglu brunatnym. 
TABELA 6. Procentowy udział frakcji niklu w analizowanej glebie

TABLE 6 . The percentage share of nickel fraction in the analysed soil

\begin{tabular}{|c|c|c|c|c|c|c|}
\hline \multirow[t]{2}{*}{$\begin{array}{l}\text { Wapnowanie } \\
\text { Liming }\end{array}$} & \multirow[t]{2}{*}{$\begin{array}{l}\text { Materiały organiczne } \\
\text { Organic materials }\end{array}$} & \multirow{2}{*}{$\begin{array}{l}\text { Nikiel } \\
\text { (mg kg } \\
\text { Nickel gleby) } \\
\text { (mg kg } \\
\end{array}$} & \multicolumn{4}{|c|}{$\begin{array}{l}\% \text { udział frakcji } \\
\% \text { share fraction }\end{array}$} \\
\hline & & & $\mathrm{F}_{1}$ & $\mathrm{~F}_{2}$ & $\mathrm{~F}_{3}$ & $\mathrm{~F}_{4}$ \\
\hline $\mathrm{Bez} \mathrm{Ca}$ & Bez mat. organicznych & 0 & 7,20 & 11,74 & 20,45 & 60,61 \\
\hline \multirow{11}{*}{ Without liming } & Without organic materials & 75 & 64,00 & 11,85 & 7,45 & 16,70 \\
\hline & & 150 & 52,71 & 9,58 & 7,99 & 29,72 \\
\hline & & 225 & 52,81 & 11,48 & 9,26 & 26,45 \\
\hline & Słoma żytnia & 0 & 5,76 & 12,23 & 44,24 & 37,77 \\
\hline & Rye straw & 75 & 40,00 & 14,00 & 35,06 & 10,94 \\
\hline & & 150 & 40,10 & 13,37 & 27,98 & 18,55 \\
\hline & & 225 & 48,58 & 13,63 & 26,97 & 11,82 \\
\hline & Węgiel brunatny & 0 & 6,41 & 12,46 & 42,35 & 38,78 \\
\hline & Brown coal & 75 & 38,13 & 14,96 & 37,85 & 9,06 \\
\hline & & 150 & 34,94 & 11,98 & 25,38 & 22,70 \\
\hline & & 225 & 41,93 & 10,99 & 21,52 & 25,56 \\
\hline $\mathrm{Ca}$ & Bez mat. organicznych & 0 & 6,03 & 9,79 & 22,41 & 61,77 \\
\hline \multirow[t]{11}{*}{ Liming } & Without organic materials & 75 & 40,68 & 7,90 & 9,22 & 42,20 \\
\hline & & 150 & 36,48 & 8,61 & 9,66 & 45,25 \\
\hline & & 225 & 44,14 & 9,23 & 8,40 & 38,23 \\
\hline & Słoma żytnia & 0 & 5,36 & 9,29 & 33,93 & 51,42 \\
\hline & Rye straw & 75 & 35,04 & 10,57 & 32,63 & 21,76 \\
\hline & & 150 & 31,89 & 10,31 & 24,90 & 32,90 \\
\hline & & 225 & 42,46 & 10,96 & 17,50 & 29,08 \\
\hline & Węgiel brunatny & 0 & 5,28 & 8,63 & 25,00 & 61,09 \\
\hline & Brown coal & 75 & 36,78 & 10,67 & 26,57 & 26,28 \\
\hline & & 150 & 32,41 & 10,71 & 20,80 & 36,08 \\
\hline & & 225 & 37,25 & 9,11 & 17,14 & 36,50 \\
\hline
\end{tabular}

W podsumowaniu przeprowadzonego doświadczenia wazonowego oraz analiz chemicznych materiału roślinnego i glebowego należy stwierdzić, że wszystkie badane w eksperymencie czynniki, tj. zróżnicowane zanieczyszczenie gleby niklem, wapnowanie, a także dodatek słomy żytniej i węgla brunatnego, wywarły istotny wpływ na zawartość niklu w biomasie kupkówki pospolitej oraz jego rozmieszczenie w wydzielonych frakcjach w glebie. Wprowadzenie niklu do gleby spowodowało zwiększenie jego zawartości w kupkówce pospolitej oraz zwiększenie jego udziału w glebie we frakcji wymiennej $\left(\mathrm{F}_{1}\right)$. Tylko na obiektach, na których nie zastosowano niklu, zawartość tego pierwiastka w trawie nie odbiegała od wartości opisywanych w literaturze (m.in. wg Kabaty-Pendias i Pendiasa 1999). Na glebie, do której wprowadzono nikiel, zawartość tego pierwiastka w roślinach przekraczała nawet kilkadziesiąt razy zawartość uznawaną za średnią, co jest zbieżne z rezultatami uzyskanymi we wcześniej prowadzonych badaniach (Kuziemska 2009). Przeprowadzone doświadczenie wykazało, że wapnowanie gleby zanieczyszczonej niklem oraz dodatek do niej słomy żyt- niej, jak również węgla brunatnego, wpływają na istotne zmniejszenie zawartości niklu w biomasie kupkówki pospolitej uprawianej na tej glebie, a także wpływają na istotne zmniejszenie udziału $\mathrm{Ni} \mathrm{w}$ glebie we frakcji wymiennej $\left(\mathrm{F}_{1}\right)$.

\section{WNIOSKI}

1. Zanieczyszczenie gleby niklem zwiększyło zawartość tego metalu w biomasie części nadziemnej kupkówki pospolitej oraz w glebie, głównie we frakcji wymiennej.

2. Wapnowanie gleby spowodowało zmniejszenie zawartości niklu w kupkówce pospolitej oraz zmniejszenie jego zawartości $\mathrm{w}$ glebie we frakcjach: wymiennej $\left(\mathrm{F}_{1}\right)$, redukowalnej $\left(\mathrm{F}_{2}\right)$ i utlenialnej $\left(\mathrm{F}_{3}\right)$, zwiększając jednocześnie jego udział we frakcji rezydualnej $\left(\mathrm{F}_{4}\right)$.

3. Zastosowane materiały organiczne (słoma żytnia i węgiel brunatny) spowodowały zmniejszenie zawartości niklu w biomasie nadziemnej kupkówki pospolitej oraz zmniejszenie jego zawartości w glebie we frakcjach: wymiennej i rezydualnej. 


\section{LITERATURA}

Badora A., 2002. Wpływ pH na mobilność pierwiastków w glebach. Zeszyty Problemowe Postępów Nauk Rolniczych, 482: 21-36.

Campel M., Nikel G., 2006. Nickel: A review of its sources and environmental toxicology. Polish Journal of Environmental Studies, 15(3): 375-382.

Domańska J., 2009. Zawartość i pobranie niklu przez rośliny przy zróżnicowanym $\mathrm{pH}$ gleb naturalnych oraz zanieczyszczonych kadmem lub ołowiem. Ochrona Środowiska i Zasobów Naturalnych, 40: 236-242.

Eisler R., 2000. Nickel. [In:] Handbook of Risk Assessment Health Hazards to human, plants and Animals. Vol. I: Metals. Boca Raton-London-New York, Levis Publishers.

Gibczyńska M., Stankowski S., 2011. Zmiany zawartości kadmu, niklu i ołowiu w trawie Festulolium braunii uprawianej na podkładach wykonanych z osadów ściekowych i popiołów fluidalnych z węgla kamiennego w połączeniu z efektywnymi mikroorganizmami. Zeszyty Problemowe Postępów Nauk Rolniczych, 565: 63-70.

Gorlach E., Gambuś F., 2000. Potencjalnie toksyczne pierwiastki śladowe w glebach (nadmiar, szkodliwość i przeciwdziałanie). Zeszyty Problemowe Postępów Nauk Rolniczych, 472: 275-296.

Jakubus M., 2012. Phytotoxicity and speciation of copper and nickel in composted sewage sludge. Journal of Elementology, 17(1): 43-56.

Jaremko D., Kalembasa D., 2011. Specjacja niklu w ornych glebach płowych opadowo-glejowych Wysoczyzny Siedleckiej. Inżynieria Ekologiczna, 27: 19-25.

Jaworska H., Bartkowiak A., Różański S., 2013. The influence of anthropogenically increased $\mathrm{pH}$ on the content and the mobility of nickel in arable soils in the surroundings of ,Małogoszcz" cement plant. Soil Science Annual, 64(1): 14-18.

Jeske A., Gworek B., 2011. Przegląd metod oznaczania biodostępności i mobilności metali ciężkich w glebach. Ochrona Środowiska i Zasobów Naturalnych, 49: 209-218.
Kabata-Pendias A., Pendias H., 1999. Biogeochemia pierwiastków śladowych. PWN. Warszawa.

Kuziemska B., 2009. Wpływ wzrastających ilości niklu w glebie na plonowanie i skład chemiczny wybranych gatunków roślin bobowatych. Rozprawa Naukowa Nr 102, Wydawnictwo AP Siedlce.

Kuziemska B., Kalembasa S., 2013. Wpływ wapnowania i dodatku osadu ściekowego na rozmieszczenie frakcji $\mathrm{Zn} \mathrm{i} \mathrm{Cr} \mathrm{w}$ glebie zanieczyszczonej niklem. Proccedings of ECOpole 7(1): 215-221.

Molas J.S., 2010. Pobieranie niklu przez rośliny kapusty (Brassica oleracea L.) i jego fitotoksyczność w zależności od formy chemicznej dodanej do podłoża. Rozp. Nauk. z. 341, ss.142. Wyd. UP Lublin.

Nakonieczny M., 2007. Struktura i funkcjonalne przystosowanie Chrysolina pardalina (Chrysomelidae, Coleoptera) do rozwoju na hiperakumulatorze niklu Berkheya coddii (Asteraceae) studium porównawcze z Chrysolina herbacea. Wydawnictwo Uniwersytetu Śląskiego, ss. 135.

Rauret G., Lopez-Sanchez J.F., Sahuquillo A., Rugio R., Davidson C., Ure A., Quevauculler P., 1999. Improvement of the BCR three step sequential extraction procedure prior to the certification of new sediment and soil reference materials. Journal of Environmental Monitoring, 1: 57-61.

Świetlik R., Trojanowska M., 2009. Metody frakcjonowania chemicznego stosowane w badaniach środowiskowych. Monitoring Środowiska Przyrodniczego, 9: 29-36.

Węglarczyk K., 2001. Skażenie gleb metalami ciężkimi ze szczególnym uwzględnieniem niklu. Biuletyn Informacyjny Instytutu Zootechniki, 39(4): 84-88.

Wowkonowicz P., Malowaniec B., Niesiobędzka K., 2001. Metale ciężkie w roślinach i glebach na trwałych użytkach zielonych w okolicach Warszawy. Ochrona Środowiska i Zasobów Naturalnych, 49: 309-319.

Received: January 19, 2015

Accepted: April 29, 2015

\title{
Effect of liming and addition of organic materials to the nickel content in biomass of cocksfoot and his fractions in soil contaminated with this element
}

\begin{abstract}
The aim of these studies was to determine the effect of soil contamination with nickel $(0,75,150$ and $225 \mathrm{mg} \mathrm{Ni}$ $\mathrm{kg}^{-1}$ soil $)$ on the content of nickel in biomass of cocksfoot and fractions of this metal in the soil under different liming $(0 \mathrm{Ca}$ and $\mathrm{Ca}$ by 1 hydrolytic acidity) and fertilization with organic materials (without the use of organic materials, straw rye and brown coal from Turow Coal Mine). Four swaths of cocksfoot gathered in the third year of a pot experiment were analyzed and fractions of nickel in the soil after the last swath of test plants were determined. Total nickel content in the plant and in the soil was determined by ICP-AES after earlier mineralization. Fractions of nickel in the soil were determined by sequential fractionation according to BCR procedure. The introduction of nickel into the soil, regardless of amount, significantly increased concentration of this metal in the biomass of cocksfoot and soil in all fractions, in particular the soluble and easily exchangeable fraction $\left(\mathrm{F}_{1}\right)$. Liming the soil and the application of organic materials decreased nickel content in the biomass of cocksfoot and its soluble fraction in soil, easy available for plants, causing the same time to increase its share in the residual fraction (liming) and oxidisable fraction (the application of organic materials).
\end{abstract}

Keywords: cocksfoot, nickel, soil, BCR method 